\title{
Social Functions of Modern Libraries as Cultural Institution
}

\author{
Elena Iu. Kachanova* \\ Khabarovsk State Institute of Culture \\ 112 Krasnorechenskaia Str., Khabarovsk, 680045, Russia
}

Received 13.02.2016, received in revised form 21.03.2016, accepted 20.04.2016

\begin{abstract}
The paper analyzes the social function of libraries in modern society, various approaches to this problem in Russian librarianship. The author characterizes the traditionally recognized social functions of a library (essential and derivative ones), justifies the need to revise the methodological approaches to library activities in connection with changes in social life, starting from the 1990s, taking into account the emergence of new industrial technologies and marketing strategies. On the example of libraries in Khabarovsk Krai, the author explores the pros and cons of the implementation of new social functions, makes a conclusion about the need of modern libraries to comply with new cultural mission.
\end{abstract}

Keywords: library, culture, social functions, marketing, information resources, cultural mission.

DOI: 10.17516/1997-1370-2016-9-6-1376-1380.

Research area: theory and history of culture.

Libraries are one of the most important cultural institutions; their role and importance in the society are based on the implementation of certain social functions. For a long time, so-called resource-based approach prevailed in the national library science. According to this approach, the main library resource is assets of documents (information resources). This amount, structure, renewability and state of assets, books and other documents stored in a library, were the basis for their activities. The composition of the funds determined the content of enlightening (educational) work with the library readers.

In the late 1970s and early 1980s, Iu.N. Stoliarov and A.V. Sokolov justified social functions of libraries in their research on library science. These functions, in turn, were divided by the essential and derivative ones.

First, essential social functions of libraries are in the spread in time and space of socially significant ideas and knowledge recorded in the documents, in order to meet the existing information needs and to create new demand. Their implementation is defined by a library "mission" (public purpose) and includes the collection, storage of documents and the organization of access to information, satisfying needs of users in information and related ones.

Three basic functions of the library were considered essential:

(c) Siberian Federal University. All rights reserved

* Corresponding author E-mail address: kachanova_elena@mail.ru 
- communicative (ensuring communication between the document and the user, both being in a particular space-time continuum, that is the organization of access to specific documents on the basis of various forms and methods of organization and provision of information services);

- cumulative (collecting in one place of different in form and content documents, which were created at different times, at different locations, by different authors);

- memorial (saving the aggregate collected documents for their further transmission to future generations).

It is obvious that libraries have been performing all the essential social function from their emergence to the present time. The library could not exist as a social institution without any one of them. These functions are not affected by the global transformations; they are stable and proven by a long history of libraries; they are inherent in libraries of all kinds and types, all countries and continents. However, different libraries implement these functions in different ways, as the fullness of assets, retention periods, the number of users and the terms of their service have their own characteristics in libraries of various types.

The derivative social functions of libraries are caused by the society desire to use the library capabilities to solve its current problems. These functions include facilitating the education and upbringing of the population, information support of scientific, industrial, educational and recreational activities of citizens. A list of these functions is uncertain and is still questioned.

The essence of these derivatives social functions is not in the direct educational and training process taking place in libraries, the organization of leisure for the population, but rather in facilitating these processes in conjunction with other social institutions: schools, colleges, universities, etc. Here a library functions as a structure to provide information support and the support of different activities. The derivative functions complement the essential ones, rather than replace them as an alternative.

Since the mid 1990s changes in the social situation have required the introduction of elements of marketing and review of methodological approaches into library activities. Libraries are turning down the "resource" concept and resort to the marketcustomer-oriented model, based on taking into account the needs of users and making them the priority. The basis of their activity is not just assets and documents available, but the needs and demands of real and potential users. Life itself puts forward new demands, which lie in the fact that the available information resources, the types, forms and methods of services provided must be adjusted to the situation. The current situation implies a set of external conditions and internal capabilities of specific library activities, which should be regularly monitored.

The mission of each library, as well as its public mission (task) depends on the conditions, namely the environment, and so it cannot be constant and the same for all people. Each individual library is a flexible structure, which should remake its activities in accordance with changes in the service area, the development of libraries in the country, the emergence of new industrial technologies, and the implementation of state (municipal) programs.

Since the 2000s, the libraries have started to use new marketing strategies: differentiation, integration, specialization and diversification. The first strategy requires the development and modification of existing library services to the needs of each user category. The second strategy, integration, allows libraries to pool resources, to save the funds available to address certain tasks, common for a group of partners. Specialization 
reduces the activity of (general) libraries to a single direction, but the priority, profile one (for specific conditions).

The most daring and controversial for the library strategy is diversification. It is based on the creation and delivery of new and innovative types of services to users, taking into account their needs. These services include service-analogues (along with books, brochures, newspapers and magazines and other media, new types of resources, such as prints, CD-drives, copies of documents etc. are available for temporary lending); and additional services, satisfying not only information needs of citizens, but also the associated ones (copying and scanning, training on speed reading and computer literacy, etc., the sale of office supplies and so on). On this basis, the library had the opportunity to extensively develop paid services, above-standard and optional ones. These include specialized library and information services of high complexity (tracking publications on the subject in foreign and Russian databases (aggregate information resources), preparation of analytical reports, making reviews for the research, annotated lists of information digests, etc.), and services borrowed from other fields of activity (like conducting courses, workshops, excursions, equipment renting, sound recording, video and photography, etc.). Marketing services' purpose is to add to the range of ordinary library services aimed at giving access to knowledge and information. These services enhance the comfort of the library and media services, and in fact, allow libraries "capturing" free sites on the knowledge, information, and leisure market.

In the Far East, as well as in the whole country, this diversification manifested in a significant expansion of the range of services provided by libraries, reaching far beyond the scope of information support of the educational process and other types of activities. Libraries work on socializationandcreativepersonalitydevelopment, patriotic education. In this case, libraries position themselves as multicultural centers, the centers of obtaining NEW contemporary knowledge and information from various channels. Moreover, libraries organize meetings with politicians, art and culture celebrities, watching and discussing films and videos, recreational evenings, children's birthdays, stage plays, regional excursions and hiking tours in the native land; open playgrounds, museums, sports areas and etc.

Municipal libraries got impressive results in the development of this strategy. The positive side is that this activity is associated with their project work. Libraries involve a lot of additional resources, significantly improving the quality of service and comfort. A striking example of such work is the library in Verkhnebureinsky District of the Khabarovsk Territory. There the employees of the central children library developed and successfully implemented a project "Nest" to create a club for parents under partnership with the District educational and governmental organizations. There are 4 areas of activities:

1. School "Droplets" of early development for children of 3-5 years (parent education on home games with the kids and on lessons on the development of speech, counting, the surrounding world). 2. School "Future high achiever" of the intellectual development dealing with preparing children of 5-7 years for the school (classes in mathematics, logic, the Russian language and the surrounding world, games that develop memory, motor skills, communication skills). 3. Theaterstudio "Sunny meadow", organizing family home performances based on folk tales. 4. Folk-studio "Folk festivals in Russia" for the study of popular traditions of celebrating Christian holidays in Russia.

However, diversification does not always allow libraries to obtain positive results. Many municipal libraries cannot stop the process of development of new activities. Additional 
services no longer complement but replace the basic range of information services of the library, which leads to deformation of its social functions. There is a departure from the prevailing ideas about the library as an institution that provides access to information, the book centers and cultural institution. Most services of libraries in terms of their mass work and the implementation of certain programs are too far from information activities, promotion of reading, and the intellectual development of the individual. Therein the danger of diversification lies. For its adequate application libraries need a clear aim, a clear conception of the changes dictated by the needs of the state task.

Any library is, above all, an organization with cultural mission. It is the institution that enables users to get access not only to books and information, but to cultural national values , allowing one to be personally involved in their creation, discussing cultural processes, to show their creative aspirations and abilities.

E.Iu. Genieva justified the legitimacy of such library activity in the first half of the 2000s. Libraries position themselves as an effective, proactive and professional sociocultural institution, as a "playground" for the reconstruction of the cultural environment, to hold creative and business meetings, debates on current topics, concerts, educational programs, quizzes, days of culture of various peoples and other different events for the organization of free time activities and social development of library users.

The essential social functions of libraries have not changed, but the possibilities of their realization in modern conditions have become different. Above all, these changes are due to the development of new information technologies and their widespread introduction in libraries. They permit increasing the volume of information collected and stored, speeding the search, expanding the range of library activities, overcoming time and space barriers, and thus making information more available.

The introduction of information technology has caused, first of all, the emergence of a new category of virtual libraries users, who wish to use the information resources of libraries based through electronic communication channels. Library service for these categories is transferred to the so-called web environment and is carried out by the library site, performing the role of its Internet representative.

For the formation of the web environment the most important resources are local history information resources, containing information about the history, science, culture, institutions, developments, the characteristics of nature, flora, fauna, and the social environment.

The introduction of information technology has significantly expanded the range of services. Libraries provide factual and conceptual, analytical services, perform verification of citations and bibliographic references, carry out online search for information, conduct training sessions.

A modern library is a significant social institution of culture, cultural and creative organization. As an open, dynamic, multilevel system, the library provides users with a variety of services (informational, educational, recreational, leisure, publishing, advertising and mediation), according to the state task, its mission and the needs of real and virtual users. Its activities are related to the monitoring of the information-educational environment, needs, demands, and are aimed at ensuring the availability of information on various data storage devices. To do this, the library uses a range of different management tools from the programoriented planning and project work to search for hidden opportunities to position itself as a social and technologically modernized institute of new 
contemporary knowledge promotion, able to participate along with other social institutions in development of the successful and competent personality of a country citizen. Only in this case, the library will be in great demand and remain a significant social institution of culture in future.

\section{Социальные функции современных библиотек как институтов культуры}

Е.Ю. Качанова

Хабаровский государственный институт культуры Россия, 680045, Хабаровск, ул. Краснореченская, 112

В статье анализируются социальные функичи библиотек в современном обществе, рассматриваютсяразличныеподходыкэтойпроблемевотечественномбиблиотековедении. Автор дает характеристику традиционно выделяемым сочуиальным функииям библиотек (сущностным и производным), обосновывает необходимость пересмотра методологических подходов к библиотечной деятельности в связи с изменениями в общественной жизни, начиная с 90-х годов прошлого века, появлением новых отраслевых технологий и маркетинговых стратегий. На примере библиотек Хабаровского края автор исследует плюсы и минусы реализации ими новых соцчиальных функиий, делает вывод о необходимости выполнения современными библиотеками культуротворческой миссии.

Ключевые слова: библиотека, культура, социильные функции, маркетинг, информационные ресурсы, культуротворческая миссия.

Научная специальность: 24.00.01 - теория и история культуры. 